\title{
ANALISIS DAN PERANCANGAN SISTEM INFORMASI PRODUKSI
}

\author{
Lea Sulaiman Saputra
}

Jurusan Komputerisasi Akuntansi, Fakultas Ilmu Komputer, Bina Nusantara University

Jln. K.H Syahdan No 9, Palmerah, Jakarta Barat 11480

lea_saputra@binus.ac.id

\begin{abstract}
The objective of this research is to help solve problems faced by some companies in production planning and controlling so it could run well and effective. The research method used is literature study, field research and interview. Good internal controlling will help increasing production. The company does not have internal auditor section that will check separately company's events and internal controlling system.
\end{abstract}

Keywords: analysis, planning, information system, production

\begin{abstract}
ABSTRAK
Tujuan penelitian yang dilakukan membantu menyelesaikan masalah-masalah yang sedang dihadapi oleh perusahaan dalam perencanaan dan pengendalian produksi agar dapat berjalan dengan efisien dan efektif. Metodologi penelitian yang digunakan oleh penulis adalah studi pustaka, penelitian lapangan dan wawancara. Pengendalian intern yang baik akan sangat menunjang peningkatan produksi. Perusahaan belum mempunyai bagian pemeriksaan intern (internal auditor) yang melakukan pemeriksaan secara terpisah terhadap kegiatan perusahaan dan pelaksanaan dari sistem pengendalian intern.
\end{abstract}

Kata kunci: analisis, perancangan, sistem informasi, produksi 


\section{PENDAHULUAN}

Dalam pembangunan bidang industri sangatlah erat hubungannya dengan produksi yang menghasilkan produk-produk yang diperlukan bagi kebutuhan hidup sehari-hari maupun kebutuhan sekunder lainnya. Oleh karena itu dalam iklim usaha sekarang yang semakin terpuruk, perusahaan perlu cepat tanggap dalam pengumpulan informasi yang berguna bagi perusahaan sehingga diperoleh keputusan yang tepat. Dan juga dalam memproduksi suatu produksi kebutuhan suatu manajemen serta sistem yang baik yang sangat berpengaruh pada mutu atau kualitas produksi yang dihasilkan. Dalam menjalankan kegiatan usahanya terlihat bahwa bidang-bidang seperti produksi bukanlah merupakan kumpulan atau bidang tertutup dan berdiri sendiri tanpa ada hubungannya dengan ibdang-bidang lain seperti pemasaran, keuangan, personalia dan lain sebagainya. Satu dengan yang lainnya saling bergantung dan berinteraksi sebagai suatu sistem.

\section{Ruang Lingkup}

Pada penelitian ini penulis memfokuskan permasalahan-permasalahan yang ada dengan membatasi ruang lingkup penelitian pada sistem produksi.

\section{Tujuan}

Tujuan penelitian yang dilakukan membantu menyelesaikan masalah-masalah yang sedang dihadapi oleh organisasi perusahaan dalam perencanaan dan pengendalian produksi agar dapat berjalan dengan efisien dan efektif.

\section{METODE}

Metodologi penelitian yang digunakan oleh penulis adalah studi pustaka, penelitian lapangan, dan wawancara.

\section{Formulir Yang Digunakan}

Dalam sistem produksi yang erat kaitannya dengan sistem pengawasan produksi, formulir atau dokumen yang digunakan adalah (1) surat order produksi, merupakan surat perintah yang dikeluarkan oleh departemen produksi yang ditujukan kepada bagian yang terkait dengan proses pengolahan produk untuk memproduksi sejumlah produk dengan spesifikasi, cara produksi dan jangka waktu seperti yang tercantum dalam order; (2) daftar kebutuhan bahan, merupakan daftar jenis dan kuantitas bahan baku yang diperlukan untuk memproduksi produk; (3) daftar kegiatan produksi, merupakan formulir yang digunakan oleh fungsi produksi untuk meminta bahan baku dan penolong untuk memproduksi produk yang tercantum pada order; (4) bukti permintaan dan pengeluaran barang gudang merupakan formulir yang digunakan oleh fungsi produksi untuk meminta bahan baku dan bahan penolong untuk memproduksi produk yang tercantum pada order; (5) bukti pengembalian gudang merupakan formulir yang digunakan oleh fungsi produk untuk mengembalikan bahan baku dan bahan penolong yang tidak terpakai; (6) kartu jam kerja merupakan kartu untuk mencatat jam kerja tenaga kerja langsung yang dikonsumsi untuk memproduksi produk yang tercantum pada order; (7) laporan produk selesai merupakan suatu laporan yang dibuat untuk fungsi produksi untuk memberitahukan selesainya produksi pesanan tertentu kepada fungsi perencanaan, pengawasan produksi, fungsi gudang, fungsi penjualan, fungsi akuntansi persediaan dan fungsi akuntansi biaya. 
Contoh-contoh formulir atau dokumen sehubungan dengan masing-masing prosedur yang bersangkutan yaitu: (1) dokumen yang berhubungan dengan penjualan barang dan penagihan piutang dagang: order penjualan, order pengiriman, faktur penjualan, voucher atau kuitansi penerimaan piutang dagang, memorandum atau nota debet dan kredit; (2) dokumen yang berhubungan dengan pembelian barang dan pembayaran hutang dagang: surat permintaan pembelian, surat permintaan penawaran harga, order pembelian, laporan penerimaan barang, faktur pembelian, dan nota debet dan nota kredit; (3) dokumen yang berhubungan dengan proses produksi: bukti permintaan bahan baku, bukti pengembalian kelebihan bahan baku dari pabrik ke gudang, kartu hadir, kartu waktu atau upah, daftar upah, daftar pembagian pemakaian bahan baku, daftar pembagian upah, kartu kalkulasi harga pokok untuk tiap pesanan atau tiap pekerjaan.

\section{Biaya Mutu}

Mutu produk yang memuaskanberjalan seiring dengan biaya produk yang memuaskan. Salah satu rintangan besar bagi pembuatan program mutu adalah adanya dugaan yang keliru bahwa pencapaian mutu yang lebih baik memerlukan biaya yang lebih tinggi, dan akan mengurangi laba. Sebenarnya pandangan ini keliru, justru dengan mementingkan biaya mutu lebih dahulu maka perusahaan bisa mendapatkan kepercayaan pelanggan dan dengan sendirinya angka penjualan akan meningkat. Dengan adanya biaya mutu maka produk yang dihasilkan akan sesuai dengan standar yang ditetapkan dan dapat menghindari kegagalan produk.

Keuntungan tambahan dari mutu yang baik adalah kerusakan semakin berkurang, pekerjaan ulang dan biaya pemeriksaan akan berkurang. Hal ini mengakibatkan penghematan biaya yang sangat besar disertai peningkatan produktivitas. Perbaikan mutu produk merupakan langkah awal menuju arah peningkatan penjualan dan laba serta penurunun biaya.

\section{ERP dan Kalangan Bisnis/Industri}

ERP menjanjikan untuk mengintegrasikan proses-proses bisnis yang berbeda dari perusahaan ke dalam sebuah arsitektur informasi terintegrasi tunggal, tetapi sistem ini juga memiliki banyak tantangan.

\section{Manfaat ERP}

Enterprise Resource Planning menjanjikan untak mengubah empat dimensi bisnis yaitu:

\section{Struktur Perusahaan dan Organisasi}

Perusahaan-perusahaan dapat menggunkaan ERP untuk mendukung struktur organisasional yang sebelumnya tidak mungkin atau untuk menciptakan sebuah budaya organisasional yang lebih berdisiplin. Sebagai contoh, mereka. dapat enggunakan ERP untuk mengintegrasikan perusahaan yang letak geogafisnya berbeda atau batasan unit bisnis atau. untuk menciptakan budaya. organisasional yang lebih seragam yang setiap orang menggunakan proses dan informasi yang sama dengan batasan fimgsional yang semakin bebas sehingga dapat membantu koordmasi fungsional silang dan informasi secara bebas mengalir ke berbagai fungsi bisnis.

\section{Manajemen: Proses-Proses Manajemen Berbasiskan Pengetahuan Firmwide}

Untuk mengotomatisasikan banyak transaksi bisms yang esensial, seperti penerimaan pesanan, pembayaran ke penmsok atau perubahan status benefit kazyawan, ERP juga dapat meningkatkan laporan manajemen dan pengambilan keputusan. Informasi yang disediakan oleh ERP distrukturisasikandi sekitar proses bisnis fungsional silang dan dapat diperoleh dengan cepat. Sebagat 
contoh, ERP membantu rnmajemen dengan lebih mudah menentukan produk yang lebih atau tidak menguntungkan. ERP dapat menyediakan manajemen dengan data yang lebih baik tentang prosesproses bisnis dan performa keseluruhan organisasi.

\section{Teknologi Unified Platform}

ERP menjanjikan untuk menyediakan perusahaan dengan sebuah platform sistem informasi dan lingkungan yang tunggal, menyatu dan mencakup seluruhnya. ERP menjanjikan untuk menciptakan sebuah tempat penyimpanan yang tunggal dan tenntegrasi yang mengumpulkan data dan seluruh proses-proses bisnis kunci.

\section{Bisnis: Operasi-Operasi yang Lebih Efisien dan Proses-Proses Bisnis Yang Menggerakkan Pelanggan}

ERP dapat membantu menciptakan fondasi untuk sebuah pergerakan pelanggan atau organisasi permintaan. Dengan mengintegrasikan proses-proses bisnis yang berlainan seperti penjualan, produksi, keuangan dan logistic, keseluruhan organisasi dapat merespon permintaan pelanggan dengan efisien untuk produksi atau informasi, meramalkan produk baru, serta membangun dan mengantarnya sebagai keperluan permintaan. Produksi memiliki informasi yang lebih baik untuk memproduksi hanya apa yang dipesan oleh pelanggan, mengadakan sejumlah komponen bahan baku yang tepat untuk mengisi pesanan aktual, melancarkan produksi dan meminimasi waktu dengan komponen atau produk jadi di dalam persediaan. Menggunakan ERP untuk menangkap data biaya unit dan kualitas, perusahaan dapat meningkatkan kualitas dan produk dan jasanya.

\section{Keuntungan ERP}

Pada dasarnya keuntungan yang paling besar dan ERP adalah integrasi. Jika kita menambah sebuah sales order yang baru ke dalam sistem, semua yang berhubungan dengan order juga berubah, termasuk komisi sales, kebutuhan inventori, jadwal manufacturing dan neraca saldo. Dengan kemampuan integrasi dan ERP, semua pegawai dapat mennggunakan informasi dan proses bisnis yang sama dan memperoleh hasil yang sama, dan sistem.

Keuntungan ERP adalah informasi real time melalui seluruh daerah fungsional organisasi, standarisasi dan ketepatan data antar perusahaan, best practices termasuk dalam aplikasi, efistensi yang terpaksa ditanggung oleh organisasi, analisa dan laporan yang bisa digunakan untuk rencana jangka panjang, informasi langsung memasuki sistem, mengijinkan customisasi, berdasarkan struktur file yang dapat diandalkan, menyediakan fungsi untuk berinteraksi dengan modul lain, menyediakan alat untuk penyelidikan sistem yang bersifat sementara.

\section{Tantangan ERP}

Walaupun ERP dapat meningkatkan koordinasi organisasional, efisiensi, dan pengambilan keputusan, tetapi ERP telah dibuktikan sangat sulit untuk dibaugun. ERP tidak memerlukan investasi teknologi yang besar tetapi juga perubahan-perubahan fundamental dalam cara pengoperasian bisnis. Perusahaan-perusahaan perlu untuk mempekerjakan kembali bisnis mereka untuk membuat informasi mengalir dengan lancar diantaranya. Karyawan-karyawan harus melakukan fungsi dan tanggung jawab pekerjaan yang baru. ERP memerlukan bagian-bagian yang kompleks dan software dan investasi yang besar dan waktu dan keahlian. ERP menimbulkan tantangan yang serius untuk perusahaan, diantaranya implementasi yang berat dan merealisasikan nilai strategis. 


\section{Implementasi yang Berat}

ERP membawa perubahan dramatis pada bisnis. Mereka memerlukan tidak hanya perubahan teknologi yang mendalam tetapi juga perubalm fundamental dalam pengoperasian bisnis. Prosesproses bisnis berubab secara dramatis, seperti struktur organisasional dan budaya. Perusahaan mengimplementasikan ERP harus ditunjang dengan definisi organization wide dan data, melatih kembali ribuan pekerja, merancang ulang proses-proses bisnis fundamentalnya, semuanya pada satu saat, ketika menjalankan bisnis seperti biasanya. Memerlukan waktu tiga hingga lima tahun untak mengimplementasikan secara penuh semua dan perubahan organisasional dan teknologi di dalam sebuah perusahaan besar. Organisasi yang tidak memahami bahwa perubahan-perubahan sepert itu akan diperlukan oleh atau bahwa tidak dapat membuatnya maka akan memiliki masalah pengimplementasian ERP, atau mereka tidak dapat mencapai tingkat yang lebih tinggi dan fungsional dan integrasi proses bisnis.

Maya di muka yang tinggi dan manfaat masa depan. Biaya-biaya dari ERP sangatlah besar di muka, tampak tinggi dan sering dibiayai secara polikal. Walaupun biaya untuk membangun sistem sangatlah jelas, manfaat sering kali tidak dapat dikuantifikasi dengan tepat pada permulaan proyek. Alasannya adalah bahwa manfaat-manfaat sering bertambah dan karyawan yang menggunakan sistem setelah sistem diselesaikan dan memperoleh pengetahuan dari operasi bisnis. Tidak fleksiblitas. Software ERP sangat kompleks dan sulit untuk dipelajari, dengan sejumlah orang yang sangat sangat sedikit dari dunia ini yang memiliki keahlian untuk meng-install dan memeliharanya. Software ini berjalan secara mendalam dengan proses-proses bisnis perusahaan. Jika perusahaan perlu untuk membuat perubahan-perubahan besar pada software, seluruh sistem harus diubah. Karena ERP adalah terintegrasi, sulit untuk membuat perubahan hanya pada satu bagian dan bisnis tanpa mempengaruhi bagian lain.

\section{Merealisasikan Nilai Strategis}

Perusahaan-perusahaan juga dapat gagal mencapai manfaat-manfaat strategis dan ERP jika pengintegrasian proses bisnis menggunakan model generik yang disediakan oleb software ERP standar untuk mencegah peerusahaan menggunakan proses-proses bisnis yang unik sebagai sumber keuntungan daripada para pesaing. Jika ERP tidak kompatibel dengan cara perusahaan melakukan bisnis, perusahaan dapat kehilangan cara baik dari pelaksanaan proses-proses bisnis kunci yang mungkin berhubungan dengan keuntungan kompefifif ERP mempromosikan koordinasi organisasional dan pengambilan keputusan secara sentralisasi, yang mungkin bukan merupakan cara terbaik untuk dioperasikan oleh bebarapa perusahaan.

\section{Apakah Ini Kegagalan ERP?}

Tidak sedikit pula, perusahaan-perusahaan yang menerapkan sistem ERP yang ternyata mampu menciptakan efisiensi. Delphi Automotive Prancis, mampu mendapatkan efisiensi. yang dtharapkan setelah menerapkan ERP. Sebelumnya sempat mengkhawatirkan keberhasilan ERP. Namun setelah menempatkan ERP secara hati-hati dalam manajemen bisnis mereka, akhimya sistem tersebut berhasil.

\section{Pelajaran Berharga}

Dari banyak kegagalm penerapan ERP beberapa bahkan banyak perusahaan belum dapat meletakkan fungsi dan kedudukan ERP dalam bisnis mereka. Akibatnya penerapan sistem ERP tidak mampu memenuhi kebutuhan bisnis. Selain itu minimnya tenaga ahli pengelola ERP pada perusahaan pengguna sistem ERP, menyebabkan sistem tidak dapat berjalan baik. Perusahaan-perusahaan di Indonesia masih melibatkan sedikit tenaga ahli dalam bagian EDP mereka. Bagi para vendor pun 
hendaknya tidak memberikan janji-janji yang menggiurkan, tetapi hendaknya memberikan fakta seandainya, sebuah sistem diterapkan. Dengan demikian tidak sepenuhnya ERP tidak layak diimplementasikan, bahkan sebenamya sangat perlu diterapkan.

\section{Alternatif Implementasi ERP}

Dalam konsep tradisional, suatu perusahaan akan membentuk tim khusus untuk implementasikan ERP. Para ahli yang diperlukan untuk menjalankan proyek implementasi sudah pasti melibatkan tenaga dan perusahaan itu, sendiri dan dibantu oleh sejumlah tenaga ahli dan sebuah vendor berkapasitas teknologi informasi (TI) atau perusahaan konsultan TI. Setelah proyek dimulai, seluruh anggota tim proyek bekerja secara full time hingga proyek selesai. Cara seperti di atas telah berjalan dengan baik di masa lalu, dan masih banyak pula diterapkan oleh berbagai organisasi.

Dengan adanya kemajuan di bidang telekomunikasi data, konsep solution center (SC) atau sentra solusi. Vendor atau konsultan yang membantu suatu perusahaan dalam menjalankan implementasi tidak seluruhnya bekerja, fulll time untuk proyek tersebut dan tidak seluruhnya bekerja on-site atau di lokasi perusahaan. Jadi ada semacam dukungan virtual yang membantu tim inti yang bekerja di lokasi proyek.

\section{Keuntungan dari Konsep Solution Center}

Banyak keuntungan yang didapatkan oleh suatu perusahaan yang memanfaatkan jasa vendor/konsultan yang mempunyai SC yang kompeten. Salah satu contoh adalah faster start up time atau dapat memulai proyek lebih cepat. Biasanya, sebelum proyek dimulai, software ERP harus membeli dan juga harus disediakan satu atau beberapa server dengan spesialisasi yang lumayan besar untuk instalasi software ERP tersebut. Sehingga. pada akhir proses procurement atau pengadaan, menunggu delivery order, dan pemasangan dapat memakan waktu. sedikitnya 1-3 bulan. Dengan menggunakan infrastruktur TI di SC dan menghubungkan data center SC ke lokasi perusahaan, maka proyek dapat segera dimulai karena sarana sudah tersedia. Jadi persiapan implementasi yang semula diperkirakan memakan wakta hingga 3 bulan atau lebih, akhirnya proyek dapat dimulai dalam 1-2 minggu saja.

Dalam menjalankan proyek keuntungan yang diperoleh adalah dari segi kualitas, dan kecepatan dalam melakukan pekerjaan. Karena SC dilengkapi oleh tenaga ahli yang telah berpengalaman dan juga dilengkapi dengan tools, process standard, dan best practices; kualitas pekerjaan akan meningkat dan diselesaikan lebih cepat. Dari pengalaman mengerjakan yang serupa, tim SC dapat juga menyelesaikan pekerjaan lebih singkat dengan memanfaatkan reusable usets atau komponen komponen yang dapat didaur ulang, hingga tidak setiap kali harus dikerjakan dari awal.

Selain itu, dengan SC suatu perusahaan juga dapat mengurangi biaya implementasi. Karena anggota tim di SC juga tidak perlu menjadi anggota tim proyek dari awal hingga akhir implementasi. Jadi hanya membenkan tenaga ke proyek tersebut pada saat tertentu sesuai kebutuhan. Dengan bantuan tim virtual di SC, jumlah anggota tim proyek dari klien yang harus berada di lokasi dapat dikurangi dan mereka dapat berkonsentrasi untuk memecahkan masalah bisnis utamanya, tidak perlu memikirkan masalah implementasi yang mendetail seperti programming dan system pendukung lainnya.

\section{Penerapan Sistem Web ERP}

Berdasarkan riset AMR, pemsahaan yang bergerak di bidang aplikasi e-bisnis, akan terjadi pergeseran prioritas dan otorisasi proses-proses internal ke arah integrasi dan interaksi eksternal. Hal ini diungkapkan olch Dave Boulanger, direktur layanan AMR. Proses-proses internal seperti 
manajemen produksi dan pengelolaan informasi yang didukung dengan sistem komputer akan dikurangi prioritasnya.

Sedangkan pengelolaan pelanggan, peningkatan penjualan dan rantai suplai akan lebih diutamakan. Hal ini dirasakan pula beberapa pengembang aplikasi bahwa proses produksi (pengembangan aplikasi) betapa. pun sulitnya masih dapat dilakukan. Beberapa vendor mulai melihat gejala ini. Mereka mulai menambahkan modul-modul untuk internet yang mendukung ERP. Beberapa alasan mulai menerapkan aplikasi Web ERP adalah (1) Instalasi program untuk aplikasi berbasis, web cukup mudah, di setiap klien tidak perlu lagi di-install program aplikasi klien, cukup sebuah web browser; (2) setiap perubahan aplikasi cukup dilakukan pada suatu server saja; (3) memungkinkan untuk mendekatkan perusahaan dengan pelanggan, pemanfaatan fasilitas e-mal, chatting, dan browsing data dan informasi. Sebuah perusahaan manufaktur di Karawang dapat melihat rencana produksi perusahaan pelanggannya di Bekasi melalui internet.

Teknologi internet semakin berkembang, internet dapat diakses, dan perangkat mobile, Palm dan Handphone.

Kendati demikian, internet masih memiliki sisi lemahnya, yaitu kecilnya bandwidth yang tersedia, hal yang sering dikeluhkan di Indonesia; keamanan fasilitas browser dengan sistem operasi masih sedikit dan terbatas misalnya, ingin mencetak laporan yang berasal dari browser. Ini merupakan sebuah pillihan. Mengenai kelebihan dan keuntungan, tergantung pada cara menyiasatinya. Penggunaan sistem Web ERP yang memanfaatkan teknologi internet masih sedikit. Green Mountain Coffee Roasters, Waterbury, Amenka, Senkat, sebuah perusahaan perdagangan telah menggunakan software ERP untuk mengelola admimistrasi, logistik, keuangan, dan pegawainya. Sistemnya cukup sederhana, seperb situs Yahoo.com atau Amazon.com yang dapat melayani kebutuhan pelanggannya. Di sisi lain, ditambahkan modul-modul pengelolaan administrasi, pelaporan, dan sebagainya. Setelah dilakukan penelitian terbadap sistem ERP mereka, ternyata $80 \%$ kegiatan dalam ERP mereka, dilakukan melalui web.

\section{Berapa Lama Sebuah Proyek ERP akan Dilakukan}

Perusahaan-perusahaan dalam meng-install ERP membutuhkan waktu yang lama. Vendorvendor ERP memberitahukan Anda kira-kira tiga atau enam bulan untuk pengimplementasimnya. Dalam sebuah perusahaan kecil pengimplementasiannya dibatasi oleh area kecil dalam perusahaan tersebut atau perusahaan hanya menggunakan bagian keuangan dari sistem ERP tersebut. Untuk penerapan ERP dengan benar Anda juga harus melakukan bisnis dengan mengubah orang-orang dalam melakukan pekerjaannya. Dan perubahan tersebut tidak selalu lancar tanpa, adanya kegagalan, kecuali melakukan bisnis dengan luar biasa hebatnya (semua pesanan dikirim tepat waktu, produktivitas lebih tinggi daripada para pesaing dan pelanggan merasa puas). Sangat penting untuk tidak meinfokuskan pada berapa lama untuk merealisasikan ERP karena sering kali biasanya sampai satu atau tiga tahun, tetapi berusahalah untuk mengerti mengapa Anda memerlukan ERP dan bagaimana Anda menggunakannya untuk memperbaiki binis Anda.

\section{Bagaimana ERP akan Memperbaiki Bisnis}

Ada lima alasan mengapa perusahaan-perasahaan menerapkan ERP, yaitu mengintegrasikan informasi keuangan, mengintegrasikan informasi pesanan pelanggan, standarisasi dan mempercepat proses pabrikasi, mengurangi persediaan, dan standarisasi informasi sumber daya manusia.

\section{Mengintegrasikan Informasi Keuangan}

CEO mencoba memahami performa perusaham secara keseluruhan, mereka akan menemukan beberapa versi perbedaan dan kebenaran. Keuangan mempunyai jumlah pendapatan tersendiri, 
penjualan mempunyai versi lam dan masing-masing unit bi Winnya, mcmpunyai versi tersendiri namun bagaimana caranya agar unit-unit bisnis tersebut memberikan kontnbusi untuk pendapatan. ERP membuat sebuah versi tunggal dan kebenaran yang tidak dapat dipertanyakan karena tiap-tiap unit bisnis menggunakan sistem yang sama.

\section{Mengintegrasikan Informasi Pesanan Pelanggan}

Sistem ERP dapat menjadi sarana/alat ketika sebuah pesanan dari pelanggan diterima dan ketika seorang pelayan konsumen menerima pesanan pelanggan tersebut sampai dengan pengisian dokumen, penginman barang dagangan dan bagian keuangan mengirimkan faktur. Dengan mempunyai informasi ini dalam sebuah sistem software, informasi lebih terdistnbusi schmgga beberapa sistem yang berbeda dapat berkomunikasi dengan yang lainnya. Perusahaan dapat mengawasi pesananpesanan yang diterima dengan lebih mudah, dapat mengkoordinasikan pabrikasi, persediaan dan pengiriman walaupun di lokasi yang berbeda dan pada waktu yang bersamaan.

\section{Standarisasi dan Mempercepat Proses Pabrikasi}

Umumnya perusahaan-perusahaan pabnkasi untuk mengembangkan usahanya akan melakukan merger atau akusisi seringkali ditemukan unit bisnis ganda bergabung dengan perusahaan lain yang mempunyai tujuan yang sama tetapi mengunakan metode dan sistem komputer yang berbeda. Sistem ERP muncul dengan metode yang standar untuk mengotomatisasi beberapa tahap dari proses pabnkasi. Standarisasi dan mengintegasikan sistem komputer dapat menghemat waktu dan mempercepat proses pabrikasi.

\section{Mengurangi persediaan}

ERP membantu arus proses pabnkasi supaya lebih lancar dan memperpendek jarak penglihatan dari pemrosesan pesanan dalam sebuah pesanan. Pengurangan persediaan dan beberpa produk yang digunakan dapat membantu user agar lebib cepat dalam penyampaian informasi kepada pelanggan dan pengiriman dokumen. Untuk memperbaiki arus dari rangkaian penawaran, Anda memerlukan rangkaian software penawaran tetapi ERP juga dapat membantunya.

\section{Standarisasi Informasi Sumber Daya Manusia}

Umumnya perusahaan-perusahaan dengan unit bisnis ganda, sumber daya manusianya tidak terintegrasi untuk itu diperlukan metode sederhana untuk mengkomunikasikannya dengan yang lainnya sehingga dapat menghasilkan manfaat dan jasa. Tiap-tiap industri mempunyai kebiasaan khusus tersendin untuk membuat perusahaannya menjadi unik. Sebagian besar sistem ERP didisain untuk digunakan oleh perusahaan pabrikasi yang mempunyai ciri tersendifi. Tiap-tiap industri mempunyai perjuangan dengan vendor-vendor ERP yang berbeda untuk memodifikasi program ERP yang mereka butuhkan.

\section{Akankah ERP Cocok dengan Cara-Cara Bisnis}

Sangatlah sulit bagi perusahaan untuk membentuk suatu sistem, jika cara perusahaan dalam melakukan bisnis akan disesuaikan dengan paket ERP standar sebelum pemeriksaan dan implementasi dimulai. Alasan yang paling umum bahwa perusahaan proyek ERP yang bernilai multi jutaan dolar adalah mereka. menemukan software yang tidak mendukung salah satu dan proses-proses bisnis yang penting. Pada point ini ada 2 hal yang dapat mereka lakukan yaitu: (1) mereka dapat mengubah proses bisnis untuk mongakomodasi software, yang mana akan menunjukkan perubahan yang mendalam pada cara-cara yang lama dan bisnis (yang sering menyediakan keuntungan kompetitif) dan menggoncangkan peran-peran dan tanggung jawab orang penting; (2) mereka dapat memodifikasi 
software guna disesuatkan dengan prosesnya yang akan memperlambat proyek, memperkenalkan bugs yang berbahaya ke dalam sistem dan meng-upgrade software dengan software peluncuran berikutuya dan vendor ERP.

Perpindahan ke ERP merupakan proyek dan jangkauan yang mendebarkan hati, dan kartu Up pada bagian muka. Dan untuk menganggarkan biaya software, eksekutif keuangan harus merencanakan biaya konsultasi, kerja ulang proses, pengujan integrasi dan biaya lain sebelum ERP mulai diwujudkan. Perkiraan biaya yang rendah untuk pengajaran proses kerja baru user dapat memberikan goncangan yang kasar, dan juga dapat gagal untuk mempertimbangkan syarat-syarat integrasi gudang data dan biaya software ekstra untuk format Japoran yang lama. Sedikit kekeliruan dalam anggaran dan perencanaan dapat menyebabkan biaya menjadi sangat tinggi daripada kekeliruan dalam perencanaan beberapa sistem informasi yang lain.

\section{Memperoleh Payback dari ERP dan Berapa Payback-nya}

Tak menyangka untuk merevolusionerkan bisnis dengan ERP, Suatu latihan yang menfokus pada optimasi cara yang dilakukan secara intemal daripada dengan pelanggan, supplier atau mitra kerja. Masih akan memperoleh payback yang baik jika reaa untuk menungguinya. Penyelidikan Meta Group terhadap 63 perusahan menemukan bahwa perusahan memerlukan waktu 8 bulan setelah sistern baru diterapkan untuk mendapatkan manfaatnya. Tetapi tabungan tahunan rata-rata dari sistem ERP baru adalah $\$ 1,6$ juta.

\section{HASIL DAN PEMBAHASAN}

Perusahaan bergerak di bidang produksi kerajinan barang-barang yang terbuat dari plastik. Adapun barang-barang yang diproduksi oleh perusahaan ini yaitu seperti tempat isi film, tempat salep atau balsam, tutup-tutup lem, tutup botol yang terbuat dari plastik, wadah untuk obat, dan lain lain sesuai dengan pesanan dari pelanggan.

Walaupun perusahaan yang berbeda Akan mencari sumber tanah yang berbeda dalam proses anggaran, pausahaan yang telah mengimplementasikan paket ERP setuju bahwa biaya-biaya tertentu lebih umum diabaikan atau diperkirakan lebih rendah daripada yang lainnya. Biaya-biaya antara lain pelatihan, integrasi dan pengujian, kustomisasi, konversi data, analisis data, konsultasi yang tiada henti, menggantikan yang terbaik dan terbijaksana, tim implementasi tidak dapat berhenti, menunggu ROI (Return on Investment), tekanan Purna ERP.

\section{Pelatihan}

Pelatihan adalah pilihan yang disepakati dan pelaksana ERP yang berpengalaman sebagai item yang paling rendah perkiraan anggaran biayanya. Biaya pelatihan tinggi karena para pekerja hampir mempelajari semua proses rangkian yang baru, bukan hanya tainpilan software yang baru. Lebih buruk lagi, perusahaan pelatihan di luar mungkin tidak mampu membantu. Mereka difokuskan untuk memberitahukan orang-orang cara menggunakan software, tidak mendidik orang-orang tentang caracara melakukan bisnis. Bersiaplah untuk mengembangkan kurikulum sendiri yang memperkenalkan dan menjelaskan proses bisnis yang berbeda yang akan dipengaruhi oleh sistem ERP.

Dengan ERP orang keuangan akan menggunakan software yang sama seperti orang gudang dan mereka akan sama-sama memasukkan informasi yang mempengaruhi sata sama lain. Untuk melakukan ini secara akurat, mereka harus mempunyai beberapa pemahaman yang lebih luas tentang perusahaan lain melakukan pekerjaan mereka daripada pekerjaan yang dilakukannya sebelum ERP 
muncul. Maka apa saja yang telah dianggarkan untuk pelatihan ERP, baik kelipatan dua atau tiga, anggaran tersebut akan terus meningkat. Ini akan menjadi mvestasi ERP yang terbaik yang pernah dibuat.

\section{Integrasi dan Pengujian}

Pengujian hubungan antar paket ERP dan hubungan software perusahaan lain yang harus dibangun pada basis kasus per kasus juga sering diperkirakan rendah biayanya. Perusahaan pabrik tertentu boleh mempunyai aplikasi tambahan dan mayor, yaitu: e-commerce dan rantai distribusi ke yang minor, yaitu: perhitungan pajak penjualan dan bar coding. Semua membutuhkan hubungan integrasi ke ERP. Jika dapat membeli tambahan dari vendor ERP yang telah diintegrasikan, mungkin dirasa kurang balk. Jika perlu membangun hubungan sendin, dan menyangka sesuatu akan menjadi jelek. Seperti dengan pelatihan, pengujian integrasi ERP telah dilakukan dari perspektif orientasi proses. Veteran menganjurkan bahwa sebagai pengganti pengisian data dummy dan untuk memindahkan dari satu aplikasi ke aplikasi berikutnya, menjalankan pesanan pembelian riil melalui sistem, dari masukan pesanan melalui pengiriman dan kwitansi pembayaran lebih disukai adanya partisipasi dari karyawan yang akhirnya akan melakukan pekerjaan itu.

\section{Kustomisasi}

Tambahan hanya merupakan permulaan dan biaya, integrasi ERP. Masih banyak biaya lainnya, dan hal yang perlu dihindari jika adalah kustomisasi aktual dari software ERP inti itu sendiri. Ini terjadi ketika software ERP tidak dapat mengatasi salah satu dari proses bisnis dan memutuskan untuk menggabungkannya dengan software lain agar dapat melakukan yang diinginkan. Kustomisasi dapat mempengaruhi setiap modul dari sistem ERP karena mereka semua terhubung erat satu sama lain. Meng-upgrade ERP merupakan suatu hal yang amat sangat sulit karena harus melakukan semua kustomisasi mulai dan awal untuk disesuaikan dengan versi yang baru. Mungkin akan berjalan, mungkin juga tidak. Apapun juga, vendor tidak akan mendukung Anda. Anda akan harus menggajikan staf ekstra untuk melakukan pekerjaan kustomisasi, dan terus memeliharanya dengan baik.

\section{Konversi Data}

Sangat tinggi biayanya untuk memindahkan informasi perusahaan seperti catatan pelanggan dan pemasok data desain produk, dan lainnya, dari sistem lama ke sistem ERP yang baru. Banyak data dalam sistem lama hanya sedikit kegunaannya. Perusahaan sering menyangkal data mereka tidak berguna hingga ketika mereka memindahkannya ke sistem client/server yang baru dengan paket ERP yang popular dibutuhkan. Sebagai akibatnya, perusahaaa-perusahaan itulah yang lebih mungkin memperkirakan biaya pemindahan yang rendah. Tetapi data yang bersih memerlukan pemeriksaan untuk mencocokkan modifikasi proses yang diharuskan atau yang dibangkitkan oleh implementasi ERP.

\section{Analisis Data}

Seringkali data dari sistem ERP harus dikombinasikan dengan data dari eksternal sistem untuk tujuan analisis. User dengan keperluan analisis yang berat seharusnya memasukkan biaya dari gudang data dalam anggaran ERP dan mereka seharusnya mengharapkan melakukan suatu pekerjaan dengan lancar. User yang mangalami kesulitan di sini memfresh semua data ERP setiap hari dalam gudang data perusahaan besar adalah sulit dan kinerja sistem ERP sangat jelek dalam menunjukkan informasi yang telah berubah dari hari ke hari, membuat update data gudang yang selektif menjadi berat. Salah satu solusi yang mahal adalah custom programming. Sistem ini akan memeriksa semua keperluan analisis data sebelum menentukan anggaran. 


\section{Konsultasi yang Tiada Henti}

Ketika user gagal merencanakan pelepasan, biaya konsultan menjadi tinggi. Untuk menghindari hal ini, peruusahaan-perusahaan seharusnya mengidentifikasi tujun untuk pihak konsultannya yang akan membantu pelatihan karyawan internal yang meliputi metrik dalam kontrak konsultan sebagai contoh sejumlah yang spesifik dari karyawan perusahan seharusnya dapat melewati sebuah tes kepemimpinan manajemen proyek.

\section{Menggantikan yang Terbaik dan Terbijaksana}

Adalah kebijaksaan yang dapat diterima bahwa kesuksesan ERP tergantung pada staf-staf yang terbaik dan terbijaksana dan bisnis dan divisi SI. Software terlalu kompleks don perubahan bisnis terlalu dramatis untuk menyebabkan penggunaan karyawan barus selektif. Berita yang buruk adalah perusahan harus bersiap untuk menggantikan banyak karyawannya ketika proyek selesai. Walaupun pasar ERP tidak semujur dulunya, para konsultan dan perusahaan-perusahaan lain telah kehilangan orang yang terbaik yang akan meneruskan perjalanan dengan penawaran gaji dan bonus yang lebih tinggi. Jika membiarkan mereka pergi, tentu akan mencari untuk mempekerjakan mereka atau seseorang yang seperti mereka kembali sebagai konsultan untuk gaji yang berlipat ganda dari yang dibayarkan sebelumnya.

\section{Tim Implementasi Tidak Dapat Berhenti}

Sebagian besar perusahaan bermaksud untuk memperlakukan implementasi ERP mereka seperti proyek software yang lain. Bila suatu sofware telah di-install maka tim yang telah telah dibentuk akan dibatalkan dan semuanya akan kembali ke pekerjaan semula. Tetapi setelah ERP, maka tidak bisa kembali ke rumah lagi. Pelakunya terlalu berharga karena mereka telah bekerja dengan baik sekali dengan ERP mereka mengetahui lebih banyak banyak tentang proses penjualan daripada orang yang menjual dan lebih hanyak tentang proses produksi daripada orang yang memproduksi. Perusahaan tidak mampu untuk mengirim orang-orang proyek kembali ke dalam bisnis karena banyak yang telah dilakukan sesudah software ERP di-install. Hanya membuat laporan untuk menarik informasi dari sistem ERP baru akan menbuat tim proyek menjadi sibuk untuk setidaknya setahun. Dan dalam analisis dan satu harapan, pengetahuan bahwa perusahaan-perusahaan mendapatkan kembali dana investasinya dalam implementasi ERP. Sayangnya, beberapa departemen IS berencana kegila-gilaan dari kegiatan menginstalasi purna ERP, dan sedikitnya masih mendirikannya dalam anggaran mereka ketika mereka memulai proyek ERP. Banyak yang dipaksakan untak mengeluarkan lebih banyak uang dan karyawan dengan segera setelah jangka waktu tertentu, lama sebelum proyek ERP memberikan suatu manfaat.

\section{Menunggu ROI (Return on Investment)}

Salah satu kesalahan dari mamajemen proyek software tradisional adalah bahwa perusahaan mengharapkan keuntungan dari aplikasi secepatnya setelab di-insiall. Harapan apapun terhadap ERP, kebanyakkan sistem tidak menampakkan nilainya hingga setelah perusahaan telah mencobanya untuk waktu tertentu dan dapat berkonsentrasi dalam peningkatan kemajuan dalam proses bisnis yang dipengaruhi oleh sistem. Dan tim proyek tidak akan diberi penghargaan sampai kerja keras mereka membuahkan hasil.

\section{Tekanan Purna ERP}

Sistem ERP sering mendatangkan kekacuan pada perusahaan yang meng-insiall-nya. Belakangan ini Deffoite Consulting mengsurvei 64 dari 500 perusahaan, satu dari empat mengakui bahwa mereka mengalami kejatuhan performa ketika sistem ERP mereka dijalankan. Persentase yang 
sebenarnya tidak perlu diragukan pasti akan lebih tinggi. Sebagian besar alasan daro masaJah performa adalah segalanya kelihatan dan bekerja bekerja berbeda dari cara yang sebelumnya. Ketika orang-orang tidak dapat melakukan pekerjaan mereka dengan cara yang terbiasa dan belum menguasai cara baru, mereka panik dan bisnis menjadi kacau.

\section{SIMPULAN}

Penulis mengambil kesimpulan yaitu bahwa pengendalian intern yang baik akan sangat menunjang peningkatan produksi. Perusahaan belum mempunyai bagian pemeriksaan intern (internal auditor) yang melakukan pemeriksaan secara terpisah terhadap kegiatan perusahaan dan pelaksanaan dari sistem pengendalian intern. Di dalam sistem produksinya telah terkandung unsur-unsur seperti pemisahan tugas dan wewenang, prosedr otorisasi serta perencanaan dan pengawasan produksi yang diselenggarakan secara baikd an tegas. Pemakaian formulir sesuai dengnakebutuhan sistem akuntansinya. Rancangan formulir yang dipakai dalam perusahaan telah mengikuti prinsip-prinsip dalam merancang suatu formulir yang baik yang juga disertai rangkapan beberapa lembar yang akan didistribusikan kepada pihak-pihak yang berkepentingan. Meskipun secara keseluruhan pelaksanaan sistem pengawasan produksi dapat dinilai cukup baik tetapi terdapat kelemahan-kelemahan, yaitu (1) pada pemakaian formulir belum digunakannya formulir yang pre numbered yang akanmemudahkan pengarsipan dan juga mudah untuk dikontrol; (2) sistem pengendalian intern yang dilaksanakan dalam perusahaan belum dilaksanakan secara menyeluruh; (3) dalam perusahaan ini tidak terdapat bagian keuangan sehingga fungsi atau tugas keuangan dilaksanakan oleh kasir.

\section{DAFTAR PUSTAKA}

O’Brien, J. (2001). Introduction to Information System (11th ed.). New York: McGraw-Hill.

Reis, J. (2002). Intranet Basic Concept and Definition, retrieved from http://www.learnthat.com/define/i/intranet.shtml

Telleen, S. (2002). Intranets as Knowledge Management Systems, retrieved from http://www.iorg.com/papaers/knowledge.html 